\title{
Oppimisvaikeudet, toimintavalmiudet ja toimijuus elämänkulussa
}

\section{Tapaustutkimus aikuisten oppimisvaikeuksista}

\author{
$y$ \\ Oppimisvaikeudet vaikuttavat kauaskantoisesti elämänkulkuun. \\ Millaiset yhteiskunnalliset reunaehdot ja rakenteelliset \\ tekijät kehystävät toimijuutta ja toimintamahdollisuuksia \\ oppimisvaikeuksia kokevilla aikuisilla? Vastausta kysymykseen \\ haettiin tapaustutkimuksen keinoin kahden aikuisen \\ kokemuksista toimintavalmiusajattelun pohjalta.
}

\section{$\boldsymbol{y}$}

OPPIMISEN VAIKEUKSIA VOI esiintyä monesta syystä elämän eri vaiheissa. Kehityksellisiä oppimisvaikeuksia pidetään synnynnäisinä ja usein aikuisuuteen ulottuvina. Yleisin oppimisvaikeus on lukivaikeus. Aikuisten kokemuksissa lukemisen ja kirjoittamisen pulmat ovat pitkäaikaisia ja voivat heijastua monin eri tavoin koulutukseen ja työelämään. (Korkeamäki 2010; de Beer ym. 2014.)

Oppimisvaikeuksien ja eriarvoisuuden tutkimus on vahvistunut useilla tieteenaloilla, ja oppimisvaikeuksien ja koettujen kouluvaikeuksien on havaittu vaikuttavan niin koulutuksen pituuteen, työttömyyteen kuin mielenterveyteenkin (Lavikainen ym. 2006; Stein ym. 2011; Livingston ym. 2018). Vaikka suomalainen koulutusjärjestelmä pyrkii tarjoamaan tukea kaikille sitä tarvitseville, monien aikuisten on havaittu jääneen ilman tarvittavaa tukea kouluaikoinaan (Lavikainen ym. 2006; Korkeamäki ym. 2017).

Oppimisvaikeuksien tutkimus painottuu vahvasti lääketieteelliseen ja psykologiseen tutkimukseen, ja oppimisvaikeuksiin kytkeytyvät sosiaaliset tekijät ovat jääneet vähemmälle huomiolle. Toisaalta on esi- 
tetty, että sosiologia on pitkälti sivuuttanut oppimisvaikeudet ja heikon lukutaidon eriarvoisuuden tutkimuksessa (Shifrer 2013; Cieslik \& Simpson 2015). Sosiologiset tutkimukset ovat kiinnittäneet erityistä huomiota oppimisvaikeuksien diagnosointiin. Yhtäältä diagnooseja on pidetty ongelmallisena sosiaalisen oikeudenmukaisuuden näkökulmasta, sillä niiden on ajateltu sijoittavan ongelmat yksilöön eikä yhteiskuntaan (esim. Ecclestone \& Brunila 2015). Toisaalta diagnoosi voi tuoda esille ongelmia tuen saamisessa (Deacon ym. 2020).

Eriarvoisuutta koskevat tutkimukset eroavat sen suhteen, kuinka vahvasti eriarvoisuuden arvioidaan johtuvan yksilöllisistä tekijöistä ja millä tavoin erilaisten yhteiskuntaan ja koulutukseen kytkeytyvien rakenteellisten tekijöiden nähdään vaikuttavan koulutuksellisen eriarvoisuuden syntyyn (Shifrer 2013).

Oppimisvaikeuksien suhde eriarvoisuuteen kytkeytyy keskusteluihin yksilöllisten ja yhteiskunnallisten tekijöiden vuorovaikutuksesta vammaisuuden tutkimuksessa. Näitä on usein lähestytty erottamalla toisistaan vammaisuuden lääketieteellinen ja sosiaalinen malli. Siinä missä lääketieteellinen malli painottaa vamman tai sairauden merkitystä vammaisuuden rakentumisessa, vammaisuuden sosiaalinen malli pyrkii tarkastelemaan yhteiskunnallisia tekijöitä, jotka vaikuttavat mahdollisuuksiin osallistua täysimääräisesti yhteiskuntaan. (Thomas 1999; Shifrer 2013.)

Lähestyn tässä tutkimuksessa oppimisvaikeuksia vammaisuuden sosiorelationaalisen mallin avulla. Sen mukaisesti ymmärrän oppimisvaikeudet biososiaalisina: biologiset ja sosiaaliset tekijät toimivat vuorovaikutuksessa keskenään ja tulevat nimetyksi erilaisissa sosiokulttuurisissa prosesseissa. Kiinnitän huomiota sekä yksilölliseen kokemukseen oppimisvaikeuksista että oppimisvaikeuksiin kytkeytyviin sosiaalisiin tekijöihin. Sosiorelationaalisessa mallissa pidetään tärkeänä myös vammaisuuden psykoemotionaalista ulottuvuutta eli vammaisuuteen usein kytkeytyviä huonommuuden tai häpeän tunteita. (Thomas 1999; Macdonald 2019.)

Kysyn tutkimuksessa, millaiset yhteiskunnalliset reunaehdot ja rakenteelliset tekijät kehystävät toimijuutta ja toimintamahdollisuuksia oppimisvaikeuksia kokevilla aikuisilla. Tarkastelen tapaustutkimuksen keinoin kahden aikuisen kokemuksia oppimisvaikeuksista osana elämänkulkua sosiaalisiin tekijöihin ja yhteiskunnalliseen kontekstiinsa kiinnittyneinä. Oppimisvaikeuksien rinnalla tarkastelen erityisesti ikää, yhteiskuntaluokkaa ja sukupuolta. Teoreettisena näkökulmana hyödynnän toimintavalmiusajattelua (esim. Robeyns 2017; Tani ym. 2019), jonka avulla liitän tutkimuksen osaksi keskustelua koulutuksellisesta eriarvoisuudesta ja sosiaalisesta oikeudenmukaisuudesta. Peilaan lopuksi tuloksia ja toimintavalmiusajattelua aikuiskasvatukseen.

\section{TOIMINTAVALMIUSAJATTELU KOULUTUKSESSA}

Toimintavalmiusajattelu pohjautuu taloustieteilijä ja filosofi Amartya Senin (2009) ja filosofi Martha Nussbaumin (2011) ajatteluun, ja sitä on pidetty tärkeänä tarkastelukulmana myös koulutuksen tutkimuksessa. Toimintavalmiusajattelun keskiössä ovat toimintavalmiudet (capabilities), joilla tarkoitetaan tosiasiallisia mahdollisuuksia tehdä arvostamiaan asioita (functions). Sen kiinnostuksen kohteena on mahdollisuuksien kirjo: mitä ihmiset voivat olla ja tehdä toimintavalmiuksien mahdollistamina. Nussbaum erottaa toimintavalmiuksista sisäiset toimintavalmiudet, joilla hän viittaa yksilön ominaisuuksiin ja kykyihin. Vaikka sisäiset toimintavalmiudet ovat yksilön ominaisuuksia, ne ovat joustavia ja dynaamisia ja kehittyvät vuorovaikutuksessa ympäristön kanssa. (Nussbaum 2011,21-23.)

Mahdollisuus kouluttautumiseen on yksi ydinvalmiuksista toimintavalmiusajattelussa, ja kouluttautumisella on sekä sisäistä että välineellistä arvoa (Walker \& Unterhalter 2007). Toimintavalmiusajattelu painottuu aikuisuuteen. Lapsuus- ja nuoruusajan koulutuksen tulisi tuottaa tiettyjä toimintoja, kuten lukutaidon, jolloin aikuisuudessa tarvittavat toimintavalmiudet mahdollistuvat (Terzi 2005).

Toimintavalmiusajattelua erityisesti koulutuksen kontekstissa kehittänyt Melanie Walker (2006) on nostanut tiedollisten tekijöiden rinnalle muita toimintavalmiuksia. Mahdollisuus tavoitella omia pyrkimyksiä, tuoda esille omia näkökulmia sekä oikeus fyysiseen ja emotionaaliseen koskemattomuuteen 


\section{MAHDOLLISUUS}

\section{KOULUTTAUTUMISEEN ON YKSI}

\section{YDINVALMIUKSISTA TOIMINTA-}

\section{VALMIUSAJATTELUSSA.}

ovat toimintavalmiuksia, joita Walkerin mukaan koulutuksen olisi erityisen tärkeä edistää. Mahdollisuus omaan ääneen on merkityksellistä ja usein muita toimintavalmiuksia edistävää (Zimmermann 2020).

Kasvatussosiologisessa keskustelussa resurssien käsite on tärkeä koulutuksellisen eriarvoisuuden näkökulmasta (Aaltonen \& Lappalainen 2013). Eriarvoisuuden tutkimuksen kannalta resurssit voivat olla sekä materiaalisia että yksilön sisäisiä (Grundmann \& Dravenau 2010). Myös toimintavalmiusajattelussa resurssit ovat tärkeitä, vaikka tosiasiallinen hyvinvointi ja mahdollisuudet toimia ovat ensisijaisia. Resurssit voidaan muuntaa toimintavalmiuksiksi erilaisten muuntotekijöiden avulla: Yksilölliset muuntotekijät ilmaisevat yksilöä ja hänen ominaisuuksiaan. Sosiaaliset muuntotekijät ovat käytäntöjä, sosiaalisia normeja, toimintatapoja tai valtasuhteita. Ympäristön muuntotekijät ovat yhteydessä fyysiseen ympäristöön kuten esimerkiksi maantieteelliseen sijaintiin. (Robeyns 2017.)

Sosiologisesta näkökulmasta toimintavalmiusajattelussa on painotettu muuntotekijöiden ohella toimijuutta (esim. Zimmermann 2006). 'Toimijuus' tuo mukaan rakenteellisten tekijöiden merkityksen yksilölliselle toiminnalle ja omille valinnoille. Samoin se kiinnittää yksilön ja saatavilla olevat mahdollisuudet historialliseen kontekstiinsa. Siirtymät ovat merkityksellisiä toimintavalmiuksien kannalta, sillä ne tekevät toimintavalmiudet ja niiden mahdolliset puutteet näkyviksi. (Zimmermann 2006.) Ihmiset kuitenkin eroavat siinä, miten resursseja saadaan käyttöön ja miten niitä pystytään hyödyntämään. Yhteiskuntaluokan huomioivassa toimijuuden tarkastelussa onkin tärkeää analysoida yksilön saatavilla olevien resurssien kokemista, tunnistamista ja käyttöä. (Grundmann \& Dravenau 2010.)

Tarkastelen oppimisvaikeuksien merkitystä elä- mänkulussa erityisesti toimintavalmiuksien ja toimijuuden näkökulmasta. Muuntotekijöinä analysoin oppimisvaikeuksien rinnalla etenkin ikää, yhteiskuntaluokkaa ja sukupuolta toimintavalmiuksia ja toimijuutta mahdollistavina ja rajoittavina tekijöinä. Toimintavalmiusajattelu ei kiinnitä huomiota vain lopputulokseen vaan myös valintojen prosessiin. Tästä näkökulmasta ihmisten omat toiveet ja pyrkimykset ovat tärkeitä, samoin niihin kytkeytyvät sosiaaliset tekijät ja normatiiviset odotukset. (Hobson 2018.)

Ikä ja sukupuoli eivät ole vain yksilöllisiä muuntotekijöitä vaan myös sosiaalisia ja rakenteellisia; ne kantavat monenlaisia sosiaalisia merkityksiä, odotuksia ja toiminnan mahdollisuuksia. Yhteiskuntaluokkaa koskevassa keskustelussa on painotettu erityisesti yksilöiden erilaisia resursseja ja kykyjä käyttää näitä resursseja, mutta luokkaa on tarkasteltu myös sisäisesti rakentuneena kokemuksena (Tolonen 2008).

\section{AINEISTO JA MENETELMÄT}

Tapaustutkimuksen aineistona ovat kahden oppimisvaikeuksia kokevan aikuisen elämänkulkua kuvaavat haastattelut. Ne ovat osa laajempaa aineistoa, jossa haastateltiin 26 aikuisen kokemuksia oppimisvaikeuksista ja niihin saadusta tuesta. Haastattelut ovat elämänhistoriallisia siinä mielessä, että niissä tarkasteltiin oppimisvaikeuksien merkitystä lapsuudesta aikuisuuteen eri elämänalueilla.

Aineisto kerättiin vuosina 2007-2009. Haastateltavat olivat 18-60-vuotiaita ja edustivat erilaisia sosiaalisia asemia. Heistä 16 oli naisia ja 10 miehiä. Kaikilla oli virallisesti todettu oppimisvaikeus, useimmiten lukivaikeus. Tein haastattelut osana Kuntoutussäätiön projektia, jossa kehitettiin tukipalveluita aikuisten oppimisvaikeuksiin (Korkeamäki 2011). Haastateltavat rekrytoitiin sekä hankkeen asiakkaista että hankkeen ulkopuolelta. Haastattelut kestivät keskimäärin tunnista kahteen. Ne nauhoitettiin ja litteroitiin sanatarkasti.

Tähän tutkimukseeni valitsin aineistosta kaksi haastateltavaa, joiden elämäkertatiivistelmien avulla analysoin toimintavalmiuksia osana elämänkulkua ja havainnollistan muuntotekijöiden, kuten iän, yhteiskuntaluokan ja sukupuolen, merkitystä oppimisvai- 
keuksia koskevissa kokemuksissa. Tarkastelen heidän saamaansa tukea sekä heidän kuvaamiaan koulutuspolkuja ja työelämäkokemuksia. Olen nimennyt haastateltavat Mariksi ja Olliksi.

Tarinoita on karkeistettu ja yksityiskohtia muutettu haastateltavien yksityisyyden suojaamiseksi. Haastateltavat olivat haastatteluhetkellä hieman alle 40-vuotiaita. Mari työskenteli osa-aikaisesti palvelualalla ja Olli asiantuntijatehtävissä. He kävivät peruskoulunsa 1970-1980-luvuilla ja kuuluvat siten peruskoulun käyneen sukupolven alkupäähän. Peruskouluun siirtyminen toi oppimisen tuen periaatteessa kaikille sitä tarvitseville erityisesti tukiopetuksen tai osa-aikaisen erityisopetuksen muodossa ja käynnisti laajamittaisen erityisopettajakoulutuksen (Jahnukainen ym. 2012).

Tapaustutkimuksen avulla voidaan tehdä oikeutta ihmisten tarinoille kokonaisuudessaan ja liittää yksilölliset elämäntarinat laajempaan yhteiskunnalliseen kontekstiin (Niemi \& Mietola 2017). Tapaustutkimuksen kannalta äärimmäisten tapausten valitseminen analysoitavaksi voi olla hyödyllistä, sillä ne sisältävät usein enemmän toimijoita ja informaatiota tutkimuksen kannalta kuin keskimääräiset tapaukset (Flyvbjerg 2006).

Tapaustutkimukseen valitut haastattelut kuvaavat monella tapaa aineiston ääripäitä, vaikka haastatteluissa oli myös yhteisiä kokemuksia. Mari ja Olli kuvasivat pitkäaikaisia oppimisen vaikeuksia erityisesti lukemisessa ja vieraissa kielissä. Suurista vaikeuksista huolimatta he kokivat saaneensa tukea puutteellisesti, mikä oli tavallista myös laajemmassa aineistossa (Korkeamäki 2010). Aikuisuudessa heidän kokemuksensa olivat kuitenkin hyvin erilaisia: Olli näki oppimisvaikeutensa vahvuutena, kun taas Marin kokemus omasta huonommuudesta oli erityisen syvä. Erilaiset tyhmyyden ja huonommuuden kokemukset olivat aineistossa tavallisia (ks. tarkemmin Korkeamäki ym. 2017).

Aloin lukea Marin ja Ollin haastatteluja rinnakkain alun perin siitä syystä, että molemmissa sukupuolen merkitys tuli koulussa vahvasti esille. Lukutapa sai minut kuitenkin kiinnittämään huomiota yhteiskuntaluokan merkitykseen sekä lapsuudessa että aikuisuudessa. Olli oli keskiluokkaisesta kodista, kun taas Marin lapsuusmuistoja luonnehtivat huono-osaisuus, monenlainen resurssien niukkuus ja huolenpidon vähäisyys. Marin ja Ollin haastatteluissa lapsuudenkodin tuomat resurssit tai niiden vähäisyys nousivat monia muita haastatteluja vahvemmin esille, joten tulkitsen niiden olleen heille erityisen merkityksellisiä.

Olen kirjoittanut Marin ja Ollin haastattelut kronologiseen järjestykseen elämäkertatiivistelmiksi (Niemi \& Mietola 2017), minkä jälkeen olen analysoinut niitä temaattisen analyysin avulla. Olen tarkastellut ikää, yhteiskuntaluokkaa ja sukupuolta oppimisvaikeuksien rinnalla ja analysoinut niiden merkitystä resurssien ja toimintavalmiuksien kannalta. Samalla olen kiinnittänyt huomiota siirtymiin koulutuksessa ja työelämässä. Analyysin tukena olen hyödyntänyt Walkerin (2006) näkemystä koulutuksessa tärkeistä toimintavalmiuksista. Erityisesti ääntä on pidetty tärkeänä toimintavalmiutena elinikäisen oppimisen kentällä (Zimmermann 2020). Analyysissa kiinnitän huomiota sekä ulkoisiin toiminnan ehtoihin että sisäisiin toimintavalmiuksiin, kuten käsityksiin omista kyvyistä.

\section{TOIMINTAVALMIUKSIEN KEHKEYTYMINEN KOULUN KONTEKSTISSA}

Oppimisvaikeudet tulivat esille jo varhaisina kouluvuosina, kun Marin ja Ollin oli vaikea oppia samassa tahdissa kuin muut. Alkujaan myönteinen kiinnostus koulua ja oppimista kohtaan vaihtui nopeasti kielteisiin koulukokemuksiin. Vaikka peruskoulu on alkuajoista saakka painottanut oppilaiden oikeutta saada tukea tarvittaessa (Lintuvuori 2019), tuen saaminen oppimisessa koettuihin vaikeuksiin oli vaikeaa Marin ja Ollin koulukokemuksissa. Samankaltaiset kielteiset koulukokemukset, tyhmäksi ja laiskaksi leimaaminen sekä tuen ulkopuolelle jääminen ovat yleisiä lukivaikeuksia ja muita oppimisvaikeuksia kokevilla aikuisilla (Korkeamäki ym. 2017; Deacon ym. 2020).

Olli kuvasi varhaisia koulumuistojaan ahdistavina: hänen osaamattomuutensa ja vaikeutensa keskittyä luokassa saivat paljon negatiivista huomiota, ja opettaja leimasi hänet tyhmäksi. Olli kertoi, kuinka vaikeuksiin reagoitiin rangaistuksilla ja julkisilla nöyryytyksillä. ”Mä en muista ite oppimisesta juuri mitään. Et se oli tosi ahistavaa jälki-istunnossa istumista tokaluokkalaiselle." 


\section{OLLIN VAIKEUKSIIN}

\section{REAGOITIIN}

RANGAISTUKSILLA JA

\section{JULKISILLA NÖYRYYTYKSILL $\ddot{\text { A. }}$}

Ollin kokemuksessa oikeus emotionaaliseen koskemattomuuteen ja kunnioitukseen eivät toteutuneet (Walker 2006). Mari puolestaan tunnisti itsensä osaksi hiljaisten tyttöjen joukkoa, jonka koulutyöhön ei kiinnitetä huomiota (esim. Gordon 2005).

"[Olin koulussa] se hiljanen tyttö siel koulunpenkillä joka ei puhunu muuta ku jos oli pakko. [--] Et mul jäi kaikki tieto pois et enhän mä ollu mistään perillä, ku emmä pystyny lukeen siin tahdis ku muut. Ja mä yritin olla siel pulpetin takana pienenä niin ettei kukaan edes kysyis multa mitään. En katsonu opettajaan, ettei se vaan nyt kysyis multa."

Ahdistavien kokemusten ohella koulutuksen tuottamat tiedolliset valmiudet jäävät vähäisiksi. Marin kokemuksessa vaikeuksien piilottamisella oli myös kielteinen merkitys oman äänen kannalta.

Oppimisvaikeuksia kokevat lapset tarvitsevat usein ylimääräistä apua koulutehtävistä suoriutumiseen. Tällainen koulun tarjoama apu on tarpeellista myös toimintavalmiuksien kannalta (Terzi 2005). Sekä Marin että Ollin kannalta koulun tarjoama tuki näyttäytyi kuitenkin puutteellisena. Mari ei kokenut saaneensa tukea koulusta eikä kotoa. Yksin kokeisiin valmistautuminen tuntui voimakkaalta muistolta vielä vuosien jälkeenkin:

"Sitte ku piti lukee kokeisiin kotona, ni sehän oli kauheeta. Piti vaan yrittää lukee, yrittää päntätä, eihän mul mitään hyviä numeroita koskaan tullu mistään."

Vaikka vaikeudet koulunkäynnissä olivat tulleet esille jo varhain, koulun erityisopettaja totesi Ollin lukivaikeuden vasta alakoulun viimeisillä luokilla, ja hän sai ensimmäisen kerran lukiopetusta. Ollin kokemuksessa oppimisvaikeuden tunnistaminen ja tuki olivat eriy- tyneitä: "Mutta opetuksessa ei huomioitu ollenkaan, vaan annettiin tukiopetusta ja kaikki muu opetus jatku ennallaan isos ryhmässä samalla tavalla." Erityisesti yläkouluun siirtymisen jälkeen tukea oli vähän tarjolla, ja Olli peitti oppimisvaikeutensa oppitunneilla häiriköimällä luokassa ja lunttaamalla kokeissa.

Erityisluokalle Olli oli kuitenkin vääränlainen: ”Mä olin hirveen kiltti, ainoot pienryhmät mitä oli, oli tarkkisluokat ja eihän sinne nyt laitettu tämmösii kavereita, mikä mä olin.” Tuen saamisen mahdollisuudet heijastavat erityisen tuen segregoivaa ja alueellisesti eriytynyttä luonnetta, jossa tukea on ollut vaihtelevasti saatavilla (Lintuvuori 2019). Samalla erityisopetuksen kontrolloiva funktio korostuu kuntouttavan sijaan (Jahnukainen 2003).

Marin vaikeuksia syvensi koulukiusaaminen, minkä hän liitti kokemuksissaan huonoon koulumenestykseen. Olli puolestaan sai paljon tukea vanhemmiltaan, sillä he tunnistivat lapsen kouluvaikeudet lukivaikeudeksi ennen opettajia. Vanhemmat yrittivät opettaa Ollille erilaisia opiskelustrategioita, mutta hän ei kokenut olleensa nuorena valmis vastaanottamaan niitä. Vanhemmilta saadun tuen ohella Ollilla oli muitakin resursseja: hän oli koulussa sosiaalisesti suosittu ja pärjäsi hyvin urheilussa. Voimavarat helpottivat heikon koulumenestyksen tuomaa huonommuuden kokemusta.

”Miks ylipäätänsä itsetunto pysy läjässä, ni on tietysti se perhe siinä ollu aina tukena. Sit mä oon liikunnallisesti erittäin lahjakas ollut [--] että kavereita oli sieltä ja oli hyvä siinä lajissa."

Resursseista huolimatta oppimisvaikeuksilla oli Ollille monia kielteisiä seurauksia. Yläkouluun mennessä hän ei ollut lukenut yhtään kirjaa kokonaan. Hän sai kielistä ehdot ja jäi luokalleen. Opettajien oli myös vaikea ymmärtää Ollin osaamattomuutta.

\section{ERIYTYVÄT AIKUISUUDEN KOKEMUKSET - AIKUISUUDEN MYÖNTEISET JA KIELTEISET SIIRTYMÄT}

Peruskoulun jälkeen Mari ja Olli suuntasivat molemmat ammatillisiin opintoihin, kuten suurin osa lukemisvaikeuksia kokevista oppilaista (Hakkarai- 
nen ym. 2015). Oppimisessa koetut ongelmat heijastuivat Marin toimintavalmiuksiin usealla eri tavalla: sekä huono koulumenestys että käsitys omasta itsestä kapeuttivat molemmat Marin toimintavalmiuksia ja valinnanmahdollisuuksia.

"Oli huonot todistukset ja itellä oli kuva että mä en osaa mitään ja mä en opi mitään ja mä meen vaan johonkin, mistä vois olla hyötyä ajattelematta ja tietämättä mitä ryhtyä tekemään.”

Mari ei muistanut saaneensa olleenkaan opintoohjausta vaan koki tehneensä ratkaisunsa yksin. Oppimisvaikeuksien ohella sukupuolella ja yhteiskuntaluokalla oli merkitystä opintoihin hakeutumisen muuntotekijöinä, sillä alanvalinnan hyödyllisyyttä on pidetty tyypillisenä koulutukseen ohjautumisen perusteena työväenluokkaisilla tytöillä (Käyhkö 2006). Samoin on havaittu, että työväenluokkaiset nuoret ovat kokeneet jääneensä ilman apua opintojenohjauksesta ja joutuneensa pohtimaan opiskeluratkaisujaan itsenäisesti (Käyhkö \& Tuupanen 1996).

Ollin peruskoulun jälkeinen opiskelupolku oli vähemmän suoraviivainen, mutta sisälsi useita toimintavalmiuksien kannalta myönteisiä siirtymiä. Olli siirtyi peruskoulun jälkeen kymppiluokalle opiskelemaan, joka oli hänelle monella tapaa merkityksellinen kokemus.

"Se oli ensimmäinen miellyttävä koulukokemus, siel ruvettiin keskustelemaan, juttelemaan, otettiin aikuisempana vastaan ja oli ihan mielettömän kiva vuosi. Mul nous yli numerolla keskiarvo. Opiskelust mä en tienny siin vaihees viel yhtään mitään.”

Ollin mukaan hänen lukutaitonsa ja opiskelutaitonsa olivat edelleen heikkoja, mutta hänen oli mahdollista osoittaa omaa osaamistaan keskustellen ja saada arvostusta osaamiselleen. Samalla Ollin oma ääni koulutuksessa vahvistui.

Kymppiluokan jälkeen Olli aloitti ammatilliset opinnot. Ne keskeytyivät rästiin jääneiden suoritusten vuoksi, ja Olli siirtyi opinnoista työelämään. Opintojen keskeyttäminen oli kuitenkin myönteinen siirtymä, sillä työelämään osallistuminen vahvisti myönteistä käsitystä itsestä ja omasta osaamisesta. Olli kuvasi kokeilleensa erilaisia töitä ja päätyneensä lopulta työskentelemään nuorten kanssa. Työkokemuksen myötä hän koki löytäneensä oman alansa ja siirtyi opiskelemaan alan oppilaitokseen. Samalla tavalla myönteiset työelämäkokemukset ja niiden kautta syntynyt tarve suorittaa alan tutkinto johtivat laajemmassa aineistossa aikuiskoulutuksessa aloittamiseen (Korkeamäki ym. 2017).

Varhaisaikuisuus oli Ollille tärkeä ajanjakso monien toimintavalmiuksien kehkeytymisessä. Olli kertoi aikuistumisen helpottaneen oppimistaan, sillä hän innostui lukemisesta, ja uusien opiskelustrategioiden omaksuminen oli aiempaa helpompaa. Vaikeuksia tuottivat edelleen vieraat kielet. Ne eivät kuitenkaan muodostuneet esteeksi opintojen suorittamiselle. Vaikka aikuisten oppimisvaikeuksista ei Ollin opiskeluaikana vielä laajalti puhuttu, Ollilla oli kyky keskustella opinnoissa tarvittavasta avusta opettajan kanssa, ja hän sai suorittaa vieraat kielet eri tavalla valmistuakseen opinnoistaan. ”Sieltä mä yllättävän hyvin paperein valmistuin [--] ja ainoastaan ruotsi oli semmonen, missä sielläki sai sovittua sen, että mä teen eri tavalla sen." Mahdollisuutta vaikuttaa omien opintojensa sisältöön ja toteutukseen on tulkittu vahvaksi ääneksi koulutuksessa (Zimmermann 2020).

Marin oppimisvaikeuksia ei havaittu myöskään toisen asteen koulutuksessa, mutta kokemistaan vaikeuksista huolimatta hän suoritti koulutuksen loppuun. Lukemiseen perustuvat opinnot olivat hänelle edelleen vaikeita, mutta ammatilliset opinnot olivat mieluisia ja tarjosivat mahdollisuuden pyytää apua opettajalta rauhallisessa ympäristössä. Mari työllistyi nopeasti opintojen suorittamisen jälkeen.

Siinä missä Ollin kokemuksessa työ oli vahvistanut myönteistä käsitystä omasta itsestä, Marin kokemukset työelämästä olivat pääosin kielteisiä. Hän koki työympäristön kuormittavana erityisesti siihen sisältyvän aikapaineen vuoksi. Toimijuuden näkökulmasta Mari yritti toimia oman hyvinvointinsa parhaaksi vaihtamalla työpaikkaa," ravasi keittiöstä toiseen".

Marin kokemuksessa käsitys omasta huonommuudesta oli ennen kaikkea sisäinen, sillä hän sai työstään hyvää palautetta. ”Se oli siellä pinnan sisällä se oma paha olo koko aika. Mitä en oo koskaan näyttäny ulospäin, sitä on aina ollu pärjäävä ja tekevä.” Mari perusti perheen nuorena, ja 


\section{VARHAINEN ÄITIYS}

\section{ON YHDISTETTY SEK $\ddot{A}$}

\section{OPPIMISVAIKEUKSIIN ETT $\ddot{A}$}

\section{YHTEISKUNTALUOKKAAN.}

kotonaolo lasten kanssa tarjosi hänelle mahdollisuuden jättäytyä hetkeksi pois työelämästä. Marin elämänkulussa sukupuoli, oppimisvaikeudet ja yhteiskuntaluokka kietoutuivat jälleen yhteen, sillä varhainen äitiys on yhdistetty sekä oppimisvaikeuksiin (Stein ym. 2011) että yhteiskuntaluokkaan (Käyhkö \& Tuupanen 1996).

\section{TOIMINTAVALMIUDET}

\section{TOIMINTAMAHDOLLISUUKSINA}

Mari sairastui aikuisena vakavaan masennukseen, mitä on oppimisvaikeuksien yhteydessä pidetty yhtenä puutteellisten tukitoimien seurauksena (Livingston ym. 2018). Mari näki masennuksensa johtuneen monesta eri tekijästä, mutta nimesi yhdeksi syyksi koulutukseen sidoksissa olevat kokemukset omasta huonommuudesta sekä koulukiusaamisen. Kuntoutumisen yhteydessä oppimisvaikeudet tunnistettiin ensimmäisen kerran, kun Mari löysi sattumalta oppimisvaikeuksista kertovan esitteen ja halusi selvittää asiaa tarkemmin.

Marin oppimisvaikeus todettiin aikuisena terveydenhuollossa. Hän koki diagnoosin ristiriitaisena: se vahvisti hänen kokemuksensa siitä, että hänellä oli oppimisvaikeuksia ja antoi selityksen koulussa ja opinnoissa koetuille vaikeuksille, mutta rajasi vahvasti tulevaisuuden opiskelumahdollisuuksia.

"Oli kyllä itelleen helpotus ja järkytys. Mul oli et koulunpenkille ei oo asiaa tosiaankaan et jos jotain opiskelee ni oppisopimus on yks vaihtoehto. Se oppiminen on niin vaikeeta ja on ollu koko elämän sitä. Jos ois aikasemmin tääki todettu ja tiedetty ni olis ollu paljo helpompaa. Ettei ois vaan ajatellu et on pelkästään tyhmä ja huono ja epäonnistunu täs maailmassa. Et ei oo mihinkään.”
Oppimisvaikeuksien diagnoosi avasi uusia toimintavalmiuksia mutta myös sulki niitä. Vaikka Mari itse koki koulutuksen tärkeänä työmahdollisuuksien lisäämiseksi, kouluttautumista koskevat toiveet jäivät kuulematta diagnosointiprosessin yhteydessä. Vaikean oppimisvaikeuden toteaminen aikuisuudessa rajasi siten opiskelumahdollisuuksia, eikä diagnosointiprosessista seurannut suoraan mahdollisuuksia parantaa opiskelussa tarvittavia taitoja. Aikuiskoulutukseen hakeutumiselle tarjottiin ensisijaiseksi vaihtoehdoksi oppisopimusta, joka tosiasiassa sisältää vähemmän tukea kuin monet muut opiskelumuodot (Käyhkö \& Melkas 2019). Diagnoosi oli vaikeaselkoinen, minkä vuoksi Marin oli vaikea ymmärtää sitä kokonaisuudessaan. "Enempi selkokielellä pitäs olla et ymmärtäis iteki jälkeenpäin ku sitä lukee."

Oppimisvaikeuden nimeäminen toimi kuitenkin tulkinnallisena resurssina (Wierenga 2009) aiemmin koetuille kouluvaikeuksille. Marin oli mahdollista nähdä itsensä aiempaa myönteisemmässä valossa ja kyseenalaistaa tuen ulkopuolelle jääminen kouluaikana. Mari osallistui oppimisvaikeuksia kokeneille aikuisille suunnatulle kurssille, joka konkretisoi todettua oppimisvaikeutta ja toi yhteenkuuluvuuden tunnetta muiden samanlaisia vaikeuksia kokevien kanssa. "Vertaistuki on tehny hirveesti. Et ku aina oon ajatellu et mä oon yksin ja ainoo tämmönen tässä maailmassa." Siinä missä huono koulumenestys oli ollut Marille yksinäisyyttä ja erillisyyttä tuottava kokemus, oppimisvaikeuden nimeäminen toi hänelle mahdollisuuden jakaa näitä kokemuksia muiden kanssa.

Ohjaajan ja vertaisryhmän kannustamana Mari hakeutui osa-aikatyöhön alalle, jonka koki tarjoavan rauhallisen ympäristön ja mahdollisuuksia oman työn hallintaan. Työn autonomiaa on pidetty erityisen merkityksellisenä työntekijöille, joilla on oppimisvaikeuksia (de Beer ym. 2014).

Marin ja Ollin kokemuksissa yhteiskuntaluokka ja siihen kytköksissä olevat resurssit heijastuivat koulun ohella työelämäkokemuksiin. Työelämässä Mari koki vaikeuksia esimerkiksi sähköpostin lukemisessa ja vieraskielisten asiakkaiden palvelemisessa. Ollille teknologia sen sijaan lisäsi toimintamahdollisuuksia, sillä hän käytti asiantuntijatehtävissä tietokonetta työn apuna. Teknologian hyödyntäminen lukivai- 
keuden yhteydessä on yleisempää keskiluokkaisilla kuin työväenluokkaisilla työntekijöillä (Macdonald \& Deacon 2019). Siinä missä Olli oli innostunut lukemaan aikuisuudessa, Marin lukeminen aikuisuudessa oli ollut vähäistä, koska hän ei ollut juuri tarvinnut lukutaitoa työssään (Linnakylä ym. 2000).

Suomalaisessa keskustelussa toimintavalmiudet on toisinaan käännetty toimintamahdollisuuksiksi, joiden on nähty paremmin tuovan esille yksilöiden mahdollisuudet valita arvostamiaan asioita (TeporaNiemi 2020, 31). Sekä Marin että Ollin kokemuksissa oppimisvaikeuden merkitys muuttui ajan kuluessa, samoin käsitys omasta itsestä ja toiminnan mahdollisuuksista. Ollille nuorena aikuisena parantunut lukutaito oli avannut resursseja oman oppimisvaikeuden ymmärtämiseen, ja aikuisena hän oli jossain määrin selvittänyt lukivaikeuttaan lukemalla siitä itse. Hän oli myös opiskellut avoimessa yliopistossa, ja koki vaihtoehtoiset koulutuspolut tärkeinä. Omien vaikeuksiensa myötä Olli koki osaavansa työskennellä tukea tarvitsevien nuorten kanssa keskimääräistä paremmin. Oppimisvaikeuden näkemistä vahvuutena on kuitenkin pidetty suhteellisen harvinaisena kokemuksena työelämää koskevissa tutkimuksissa (de Beer ym. 2014).

Vaikka Mari koki, että oppimisvaikeuksien diagnoosi rajasi hänen opiskelumahdollisuuksiaan, hänen käsityksensä omasta itsestä ja saatavilla olevista opiskelumahdollisuuksista oli laajentunut oppimisvaikeuden nimeämisen ja vertaisryhmään osallistumisen myötä. Mari tunnisti aiempaa paremmin omia resurssejaan, mitä voi pitää merkityksellisenä toimintavalmiuksien ja toimijuuden näkökulmasta (Grundmann \& Dravenaus 2010).

"Oon huomannu et mä osaan itse asiassa vaikka mitä vaikka mulla tää lukivaikeus onki et en mä oo ihan tyhmä ja surkee ja et on kumminki asioita joita mä osaan hyvin ja on tullu semmonen itseluottamus ja varmuus tähän elämään ja osaa arvostaa tasavertaisena muitten kanssa, mikä oli hirveen vaikeeta aina ollu. [--] Et osaa hakee niitä omia reittejään, miten oppii sitten uusia asioita. Et se on suuri helpotus, mitä ei osannu sillon aikasemmin millään tavalla jaotella tämmösiä asioita."
Mari suunnitteli aloittavansa englannin kielen opiskelun työväenopistossa hankkiakseen itselleen työssä tarvitsemiaan taitoja. Tasavertaisuuden kokemuksen ja omien resurssien tunnistamisen kannalta erityisen merkityksellisenä hän piti osallistumista diagnoosin saamisen jälkeen vertaisryhmään ja sieltä saamaansa sosiaalista tukea. Mari toi kokemuksessaan esille oppimisvaikeuksien varhaisen tunnistamisen tarpeen sekä tarvittavan ohjauksen merkityksen itselle soveltuvan alan kannalta. Suurista vaikeuksistaan huolimatta Mari koki aikuisena avun saamisen oppimisvaikeuksiin pitkälti sattumanvaraisena.

\section{POHDINTA}

Mahdollisuus kouluttautua ja tehdä omaa koulutusta ja työuraa koskevia valintoja on yksi perustava toimintavalmius. Samoin koulutus ja riittävä lukutaito mahdollistavat monia muita tärkeitä asioita yhteiskunnassa. Toimintavalmiusajattelussa yksilön toimijuus ja toimintavalmiudet ovat kytköksissä erilaisiin yksilöllisiin ja sosiaalisiin muuntotekijöihin, ja samanlainenkin yksilöllinen tekijä voi saada erilaisen merkityksen suhteessa yksilön ja ympäristön tarjoamiin resursseihin. (Robeyns 2017.)

Tässä tutkimuksessa olen tarkastellut, millaiset yhteiskunnalliset reunaehdot ja rakenteelliset tekijät kehystävät toimijuutta ja toimintamahdollisuuksia oppimisvaikeuksia kokevilla aikuisilla. Tutkimus havainnollistaa iän, sukupuolen ja yhteiskuntaluokan merkitystä oppimisvaikeuksia kokevien elämänkulussa. Olen analysoinut toimijuutta ja toimintavalmiuksia prosessina, jossa myös aika rajaa toiminnan mahdollisuuksia. Tutkimus osoittaa, kuinka koulutus voi pettää lupauksensa: se ei turvaa kaikille riittävää lukutaitoa ja voi osaltaan vaikuttaa kielteisesti minäkuvaan ja mahdollisuuksiin nostaa esille omia tuen tarpeita. Oppimisvaikeuksiin kytkeytyvät tiedot ja taidot, kuten ongelmat lukutaidossa ja vieraiden kielten taidossa, voivat olla merkityksellisiä edelleen aikuisuudessa.

Oppimisessa koettujen ongelmien ohella olen analysoinut koulutuksen tuottamia huonommuuden kokemuksia, jotka muovaavat käsitystä omasta itsestä ja omista mahdollisuuksista. Näillä kokemuksilla 


\section{YHTEISKUNTALUOKKA}

\section{HEIJASTUI SEK $\ddot{A}$ LAPSUUTEEN \\ ETT $\ddot{A}$ AIKUISUUTEEN JA}

\section{TARJOSI ERILAISIA RESURSSEJA \\ OPPIMISVAIKEUKSIEN KANSSA \\ EL $\ddot{A M I S E E N . ~}$}

voi olla pitkäaikaisia seurauksia vielä aikuisuudessa (Cieslik \& Simpson 2015). Käsitykset itsestä ja omista mahdollisuuksista voi tulkita sisäisiksi toimintavalmiuksiksi, joita koulutuksessa on tärkeä edistää tiedollisten valmiuksien ohella (Walker 2006; Nussbaum 2011).

Tutkimus osoittaa, kuinka koulutuksessa epäonnistuminen ja huono koulumenestys paikantuvat helposti yksilöön. Vaikeuksien nimeäminen oppimisvaikeuksiksi tarjosi resursseja henkilökohtaiseen ymmärrykseen, mutta näyttäytyi yhteiskunnan tasolla vaillinaisena ja eriarvoisena tapana edistää toimintavalmiuksia. Diagnosointia koskevat kriittiset keskustelut ovatkin nostaneet esille näiden prosessien ristiriitaisuuden sosiaalisten ongelmien ratkaisuissa (Ecclestone \& Brunila 2015). Tulokset heijastavat oppimisvaikeuksille tyypillistä tunnistamisen ja tukitoimien eriytymistä (Danforth 2009), mikä oli haitallista sekä lapsuuden että aikuisuuden kokemuksissa.

Peruskoulun alkuajoista saakka julkisessa keskustelussa on painottunut huoli poikien koulumenestyksestä ja PISA-arviointien myötä myös lukutaidosta (esim. Lahelma 2018). Tämä näkökulma on sivuuttanut tyttöjen koulunkäyntivaikeudet ja niiden merkityksen elämänkulun kannalta. Vähemmälle huomiolle on jäänyt, että miesten ja naisten väliset lukutaitoerot ovat pieniä, kun niitä mitataan aikuisilla. Sukupuolen sijaan yhteiskuntaluokka kytkeytyy vahvasti vähäiseen lukutaitoon aikuisuudessa. (OECD 2020.) Tarvetta olisikin tarkastella koulutukselliseen eriarvoisuuteen kytkeytyviä eroja elämänkulussa nykykeskusteluja hienovaraisemmin ja lapsuutta ja nuoruutta pidemmän ajan kuluessa.
Tässä tutkimuksessa yhteiskuntaluokan merkitys heijastui sekä lapsuuteen että aikuisuuteen, ja se tarjosi erilaisia resursseja oppimisvaikeuksien kanssa elämiseen. Koulun tukitoimien ulkopuolelle jääminen oli erityisen haitallista tilanteessa, jossa muutkin resurssit olivat vähäisiä. Samantyyppisiä tuloksia yhteiskuntaluokan merkityksestä on saatu brittiläisistä tutkimuksista, joissa heikko lukutaito, huono-osaisuus ja tuen puute kytkeytyivät toisiinsa (Parsons \& Bynner 2007; Cieslik \& Simpson 2015). Koulutuksessa epäonnistumisen ja näkymättömyyden kokemukset voivat kietoutua myös muihin sosiaalisiin eroihin, kuten yhteiskuntaluokkaan (Reay 2006). Toisaalta oppimisvaikeuksien tapauksessa erilaiset psykoemotionaaliset vaikutukset näyttäisivät olevan yleisiä myös keskiluokkaan kuuluvilla (Deacon ym. 2020).

Toimintavalmiusajattelua on arvosteltu siitä, että se on liiaksi yksilöön keskittyvää. Vaikka toimintavalmiusajattelu kohdistuu yksilöön, se ei tarkoita yksilön näkemistä irrallisena yhteiskunnasta ja sen rakenteista. Tärkeänä on pidetty, että yksilö nähdään osana ympäristöään ja muuntotekijöitä analysoidaan kokonaisvaltaisesti. (Robeyns 2017, 64.) Toimijuuttakin on mahdollista tarkastella kollektiivisena. Sosiaalisella tuella - perheellä, arvostavalla kouluyhteisöllä ja oppimisvaikeuksiin kiinnittyvällä vertaisryhmällä oli erityistä merkitystä toimintavalmiuksien kehkeytymisessä niissä tilanteissa, joissa yhteiskunnalliset instituutiot olivat vastanneet vaillinaisesti oppimisvaikeuksia kokevien tarpeisiin. Sosiaalista tukea onkin pidetty aikuiskoulutuksessa tärkeänä muuntotekijänä (Zimmermann 2020) ja resursseja välittävänä tekijänä (Wierenga 2009).

Vammaisuuden sosiorelationaalinen näkökulma ei näe koulutukseen osallistumisen esteitä ja yhteiskunnallista eriarvoisuutta universaaleina, vaan eri ryhmillä nämä saattavat johtua eri tekijöistä (Macdonald 2019). Olen tarkastellut aikuisia, jotka ovat saaneet vaillinaisesti tukea oppimisvaikeuksiinsa. Tutkimuksen etuna on elämänkulun näkökulma, joka tarkastelee toimintavalmiuksien kehkeytymistä ja toimijuutta prosessina pitkällä aikavälillä koulutuksessa ja työelämässä. Vaikka tapaustutkimuksen tulokset eivät ole sellaisenaan yleistettävissä, tapaustut- 
kimuksen antina on nähty sen kiinnittyminen yhteiskunnalliseen kontekstiin ja yksilöiden elämänkulun huomioiminen kokonaisuudessaan. Tapaustutkimus voi myös tarjota aineksia eriarvoisuutta koskevalle määrälliselle tutkimukselle. (Flyvberg 2006; Niemi \& Mietola 2017.)

Koulutuksen tiedetään kasautuvan aikuisuudessa sinänsä tasa-arvoisista koulutusmahdollisuuksista huolimatta. Erilaiset toimintavalmiudet ja niitä mahdollistavat resurssit kumuloituvat ja vaikuttavat toinen toisiinsa, mitä tämä tutkimus havainnollistaa, samoin kuin erilaisten siirtymien ja kriisien merkitystä toimintavalmiuksien ja niiden puutteiden esiin nousemisessa (myös Zimmermann 2006). Aikuisuus ja aikuistuminen näyttävät tarjoavan ainakin osalle oppimisvaikeuksia kokevista kouluttautumisen suhteen myönteisiä siirtymiä ja mahdollisuuksia toisin tekemiseen, mitä on pidetty tärkeänä toimijuuden näkökulmasta (Eteläpelto ym. 2011). Aikuisuus voi tarjota uudenlaisia resursseja sekä vaihtoehtoisia tulkintamahdollisuuksia aiemmille koulunkäyntivaikeuksille ja omille kyvyille.

Lapsuus- ja nuoruusaika on merkityksellistä toimintavalmiuksien kehkeytymiselle. Toimintavalmiuksien kirjoon ja niitä mahdollistaviin resursseihin - ja siten koulutukselliseen eriarvoisuuteen - on kuitenkin mahdollista vaikuttaa aikuisuudessa. Tämän tutkimuksen ja laajemmin toimintavalmiusajattelun näkökulmasta nykyinen aikuiskoulutusjärjestelmä olettaa aikuiset monella tapaa valmiiksi tekemään koulutuksellisia ratkaisuja. Esimerkiksi koulutuksena toteutuvassa ammatillisessa kuntoutuksessa ja aikuiskoulutustuessa painottuvat tulonsiirrot ja suoritettavat tutkinnot, vaikka ne voisivat sisältää ohjauksellisia elementtejä. Aikuisille erityisopetusta on tarjolla lähinnä vain, jos opiskelee jo ammatillisessa koulutuksessa. Monia aikuisten ohjauspalveluja luonnehtii paikallisuus ja projektimuotoisuus. Tämän tutkimuksen valossa tarvittavan tuen saaminen aikuisena esimerkiksi opiskelua haittaaviin lukutaito-ongelmiin näyttäytyy ongelmallisena ja sattumanvaraisena.

Toimintavalmiusajattelua on pidetty hyödyllisenä lähtökohtana koulutuksen sosiaalisen oikeudenmukaisuuden tutkimuksessa, sillä sen painopiste ei ole pelkästään saavutetuissa toiminnoissa, kuten suoritetuissa tutkinnoissa tai lukutaidossa, vaan laajemmin näitä toimintoja mahdollistavissa asioissa (Walker \& Unterhalter 2007). Sen on nähty tarjoavan konkreettisia mahdollisuuksia sosiaalisen oikeudenmukaisuuden edistämiseksi. Erityisesti on tarpeen huomioida vaikeuksia kokevien ihmisten omat näkökulmat ja ehdotukset toimintavalmiuksien edistämiseksi. (Abel \& Frohlich 2012.)

Ääni koulutuksessa tarkoittaa sekä mahdollisuutta nostaa esille omia kouluttautumista koskevia toiveita että mahdollisuutta vaikuttaa koulutuksen toteutukseen ja sisältöihin (Zimmermann 2020). Ingrid Robeyns (2017) esittää, että mitä selkeämpi kuva on tarvittavista resursseista ja niihin kytkeytyvistä muuntotekijöistä, sitä paremmin pystytään laajentamaan ihmisten toimintavalmiuksia ja suunnittelemaan tarvittavia tukitoimia.

Oppimisvaikeuksien on havaittu olevan yhteydessä eriarvoisuuteen monella tapaa. Siitä on kuitenkin erimielisyys, kuinka vahvasti eriarvoisuutta tuottavat tekijät paikantuvat nimenomaisesti oppimisvaikeuksiin ja mikä rooli on koulutukseen ja yhteiskuntaan kytkeytyvillä rakenteellisilla tekijöillä. Erilaiset yksilölliset ja sosiaaliset tekijät ovat vuorovaikutuksessa keskenään ja sekoittuvat ja sulautuvat toisiinsa (Zimmermann 2006), mitä tämä tutkimus havainnollistaa.

Toimintavalmiusajattelu on yksi mahdollisuus ylittää vastakkaisuus yksilöllisten ja sosiaalisten tekijöiden välillä, sillä se painottaa toimintavalmiuksia ja yksilölle itselleen tärkeitä toimintoja muuntotekijät huomioiden (Terzi 2005). Oppimisvaikeuksien, lukutaidon ja yksilön kyvykkyyttä koskevien käsitysten näkeminen vuorovaikutuksessa sosiaalisten tekijöiden kanssa auttaa tunnistamaan yhä laajemmin niitä yhteiskunnallisia esteitä, jotka vaikeuttavat koulutukseen osallistumista aikuisilla.

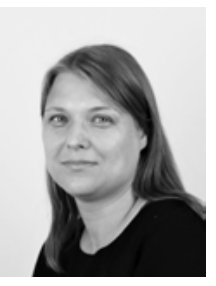

JOHANNA KORKEAMÄKI

VTM, HuK, tutkija

Kuntoutussäätiö; Helsingin yliopisto

(D) https://orcid.org/0000-00030962-6475 
Aaltonen, S. \& Lappalainen, S. (2013). Samalla viivalla? Koulutuspolulta poikenneiden nuorten resurssit ja toisen asteen koulutus. Teoksessa K. Brunila, K. Hakala, E. Lahelma \& A. Teittinen, (toim.) Ammatillinen koulutus ja yhteiskunnalliset eronteot. Gaudeamus, Helsinki, 110-127.

Abel, T. \& Frohlich, K. (2012). Capitals and capabilities: linking structure and agency to reduce health inequalities. Social Science \& Medicine 74(2), 236-244. https://doi.org/10.1016/j. socscimed.2011.10.028

Beer, de, J., Engels, J., Herkeens, Y. \& van der Klink, J. (2014). Factors influencing work participation of adults with developmental dyslexia. A systematic review. BMC Public Health 14 (77). https://doi. org/10.1186/1471-2458-14-77

Cieslik, M. \& Simpson D. (2015). Basic skills, literacy practices and the 'hidden injuries of class'. Sociological Research Online 20(1), 1-12. https://doi. org/10.5153/sro.3569

Danforth, S. (2009). The incomplete child: An intellectual history of learning disabilities. New York: Peter Lang.

Deacon, L., Macdonald, S., \& Donaghue, J. (2020). "What's wrong with you, are you stupid?" Listening to the biographical narratives of adults with dyslexia in an age of 'inclusive' and 'anti-discriminatory' practice. Disability \& Society, 1-21. https://doi.org/1 $0.1080 / 09687599.2020 .1815522$

Ecclestone, K. \& Brunila, K. (2015). Governing emotionally vulnerable subjects and 'therapisation' of social justice. Pedagogy, Culture \& Society 23(4), 485-506. https://doi.org/10.1080/14681366.2015. 1015152

Eteläpelto, A., Heiskanen, T. \& Collin, K. (2011). Vallan ja toimijuuden monisäikeisyys. Teoksessa A. Eteläpelto, T. Heiskanen, \& K. Collin (toim.) Valta ja toimijuus aikuiskasvatuksessa. Aikuiskasvatuksen 49. vuosikirja. Helsinki: Kansanvalistusseura \& Aikuiskasvatuksen Tutkimusseura.

Flyvbjerg, B. (2006). Five misunderstandings about casestudy research. Qualitative Inquiry 12(2), 219-245. https://doi.org/10.1177/1077800405284363

Gordon, T., Holland, J., Lahelma, E. \& Tolonen, T. (2005). Gazing with intent: ethnographic practice in classrooms. Qualitative Research 5(1), 113-131. https://doi.org/10.1177/1468794105048659

Grundmann, M. \& Dravenau, D. (2010). Class, Agency and Capability. Teoksessa H. Otto \& H. Ziegler (toim.) Education, welfare and the capabilities approach. A European perspective. Opladen: Barbara Budrich.

Hakkarainen, A., Holopainen, L., \& Savolainen, H. (2015). A five-year follow-up on the role of educational support in preventing dropout from upper secondary education in Finland. Journal of Learning Disabilities 48(4), 408-421. https://doi. org/10.1177/0022219413507603

Hobson, B. (2018). Gendered dimensions and capabilities: Opportunities, dilemmas and challenges. Critical Sociology 44(6), 883-898. https://doi. org/10.1177/0896920516683232

Jahnukainen, M. (2003). Laman lapset? Peruskoulussa erityisopetusta saaneiden oppilaiden osuuksien tarkastelua vuodesta 1987 vuoteen 2001. Yhteiskuntapolitiikka 68(5), 501-507.

Jahnukainen, M., Pösö, T., Kivirauma, J. \& Heinonen, H. (2012). Erityisopetuksen ja lastensuojelun kehitys ja nykytila. Teoksessa M. Jahnukainen (toim.) Lasten erityishuolto ja -opetus Suomessa. Tampere: Vastapaino.

Korkeamäki, J. (2010). Aikuisten oppimisvaikeudet. Näkökulmia selviytymiseen. Kuntoutussäätiön tutkimuksia 83. Helsinki: Kuntoutussäätiö.

Korkeamäki, J. (2011). Myös aikuiset tarvitsevat tukea oppimisvaikeuksiin. Aikuiskasvatus 31(2), 128-135. https://doi.org/10.33336/aik.93924

Korkeamäki, J., Haarni, I. \& Seppälä U. (2017). Oppimisvaikeuksien ja tarkkaavuuden vaikeuksien sosiaalinen rakentuminen ja toimijuus. Teoksessa S. Karvonen, L. Kestilä \& T. Mäki-Opas (toim.) Terveyssosiologian linjoja. Helsinki: Gaudeamus, 205-226.

Käyhkö, J. \& Melkas, H. (2019). Erityisen tuen toimintaprosessit oppisopimuskoulutuksessa. Ammattikasvatuksen aikakauskirja 21(1), 64-85.

Käyhkö, M. (2006). Siivoojaksi oppimassa. Etnografinen tutkimus työläistytöistä puhdistuspalvelualan koulutuksessa. Joensuu: Joensuu University Press.

Käyhkö, M. \& Tuupanen, P. (1996). Työläisperheestä opintielle. Reproduktion ilmeneminen nuorten arkielämässä. Teoksessa A. Antikainen \& H. Huotelin (toim.) Oppiminen ja elämänhistoria. Aikuiskasvatuksen vuosikirja 37. Helsinki: Kansanvalistusseura ja Aikuiskasvatuksen Tutkimusseura, 109-158.

Lahelma, E. (2018). Vielä kerran pojat! Kasvatus. Suomen kasvatustieteellinen aikakauskirja 49(3), 238-239.

Lavikainen, H., Koskinen, S., Aro, H., Kestilä, L., Lyytinen, H., Martelin, T., Pensola, T., Rahkonen, O., Aromaa, A. (2006). Kouluvaikeuksien yleisyys ja yhteydet aikuisiän elämäntilanteeseen ja koettuun terveyteen. Yhteiskuntapolitiikka 71(4), 402-410.

Linnakylä, P., Malin, A., Blomqvist, I. \& Sulkunen, S. (2000). Lukutaito työssä ja arjessa. Jyväskylä: Jyväskylän yliopisto. 
Livingston, E., Siegel, L \& Ribary, U. (2018) Developmental dyslexia. Emotional impact and consequences. Australian Journal of Learning Difficulties 23 (2), 107135. https://doi.org/10.1080/19404158.2018.1479975

Lintuvuori, M. (2019). Perusopetuksen oppimisen ja koulunkäynnin tuen järjestelmän kehitys tilastojen ja normien kuvaamana. Kasvatustieteellisiä tutkimuksia. Helsinki: Helsingin yliopisto.

Macdonald, S. (2019). From 'Disordered' to 'Diverse': Defining Six Sociological Frameworks Employed in the Study of Dyslexia in the UK. Insights into Learning Disabilities 16(1), 1-22.

Macdonald, S. \& Deacon, L. (2019). Twice upon a time. Examining the effect socio-economic status has on the experience of dyslexia in the United Kingdom. Dyslexia 25(1), 3-19. https://doi.org/10.1002/dys.1606

Niemi, A. M., \& Mietola, R. (2017). Between hopes and possibilities. (Special) educational paths, agency and subjectivities. Scandinavian Journal of Disability research, 19 (3), 218-229. https://doi.org/10.1080/15 017419.2016 .1239588

Nussbaum, M. (2011). Creating capabilities. Harvard University Press.

OECD (2020). Continuous Learning in Working Life in Finland. Getting Skills Right. Paris: OECD Publishing.

Parsons, S. \& Bynner, J. (2007). Illuminating disadvantage. Profiling the experiences of adults with Entry level literacy or numeracy over the lifecourse. London: NRDC

Reay, D. (2006). The zombie stalking English schools. Social class and educational inequality. British Journal of Educational Studies 54(3), 288-307.https://doi. org/10.1111/j.1467-8527.2006.00351.x

Robeyns, I. (2017). Wellbeing, Freedom and Social Justice. The Capability Approach Re-examined. Cambridge: Open Book Publishers.

Sen, A. (2009). The Idea of Justice. London: Penguin.

Shifrer, D. (2013). Learning disabilities and inequality. Sociology Compass 7(8), 656-669. DOI: https://doi. org/10.1111/soc4.12055

Stein, D., Blum, N. \& Barbaresi, W. (2011). Developmental and behavioral disorders through the life span. Pediatrics 128(2), 364-373. https://doi.org/10.1542/ peds.2011-0266
Tani, S., Kiilakoski, T., \& Honkatukia, P. (2019). Toimintavalmiusajattelu nuorisotyön, kasvatuksen ja opetuksen kentillä: kokonaisvaltainen näkökulma nuorten hyvinvoinnin edistämiseen? Kasvatus \& Aika 13(3), 4-25. https://doi.org/10.33350/ ka. 80151

Tepora-Niemi, S. M. (2020). Eriarvoisuus työelämässä ja kuntoutuksessa: Vakavasti sairastuneen ja vammaisen henkilön toimijuus elämänkulussa. Helsinki: Diakoniaammattikorkeakoulu.

Terzi, L. (2005). Beyond the dilemma of difference. The capability approach to disability and special educational needs. Journal of philosophy of education 39 (3), 443-459. https://doi.org/10.1111/ j.1467-9752.2005.00447.x

Thomas, C. (1999). Female forms. Experiencing and understanding disability. McGraw-Hill Education (UK).

Tolonen, T. (2008). Yhteiskuntaluokka: menneisyyden dinosauruksen luiden kolinaa? Teoksessa T. Tolonen (toim.) Yhteiskuntaluokka ja sukupuoli. Tampere: Vastapaino, 8-17.

Walker, M. (2006). Towards a capability-based theory of social justice for education policy-making. Journal of Education Policy 21(2), 163-185. https://doi. org/10.1080/02680930500500245

Walker, M. \& Unterhalter, E. (2007). The capability approach. Its potential for work in education. Teoksessa M. Walker \& E. Unterhalter (toim.) Amartya Sen's Capability Approach and Social Justice in Education. New York: Palgrave Macmillan, 1-18.

Wierenga, A. (2009). Young people making a life. Palgrave Macmillan.

Zimmermann, B. (2006). Pragmatism and the capability approach: challenges in social theory and empirical research. European Journal of Social Theory 9, 467-484. https://doi. org/10.1177\%2F1368431006073014

Zimmermann, B. (2020). Employee voice and lifelong education capabilities in France and Germany: two models of responsibility. International Journal of Training and Development 24(3), 265-282. https:// doi.org/10.1111/ijtd.12196 